\title{
Influence of urban planning documentations on the development of urban areas
}

\author{
Karina Ainullina, ${ }^{1, *}$, and Alexander Kryahtunov ${ }^{1}$ \\ ${ }^{1}$ Industrial University of Tyumen, 625000, 38 Volodarsky st., Tyumen, Russia
}

\begin{abstract}
In the Russian Federation, a harmonious system of urban planning documentation has developed. it is represented by three main documents: the general plan of the city, the rules of land use and development, documentation on the planning of the territory. This system of urban planning documentation is designed to solve all management decisions.
\end{abstract}

\section{Introduction}

At the present stage of rapid urban development, special attention is paid to urban development, covering a range of socio-economic, construction-technical, architectural and sanitary standards. Urban development activities are aimed at the spatial development of the city as a whole, creating a comfortable living environment for the population.

Urban development, according to the Urban Planning Code of the Russian Federation, refers to activities for the development of territories, including cities and other settlements, inter-settlement territories, carried out in the form of territorial planning, urban planning zoning, architectural design, construction, overhaul, reconstruction of capital construction facilities, operation of buildings.

Urban planning management is divided into powers according to the levels of government: the Russian Federation, constituent entities of the Russian Federation and municipalities in the field of urban planning (Table 1).

The Constitution of the Russian Federation establishes the right of every resident to a favorable living environment. This position is very important for understanding the main purpose of urban development. To achieve it, must follow the rules:

1. Meet the requirements of safety established by the legislation of the Russian Federation, rational nature management and preservation of cultural heritage objects.

2. Conform with the goals of economic and social development of the city.

3. Take into account the diversity of state, public and private interests.

\footnotetext{
* Corresponding author: ajnullinakn@tyuiu.ru
} 
Table 1. Powers of levels in the power of the Russian Federation in the field of urban development.

\begin{tabular}{|c|c|c|}
\hline Russian Federation & $\begin{array}{c}\text { Constituent entities of the } \\
\text { Russian Federation } \\
\text { preparation and approval of } \\
\begin{array}{c}\text { preparation and approval of } \\
\text { of the Russian Federation } \\
\text { territorial planning documents } \\
\text { of constituent entities of the } \\
\text { Russian Federation }\end{array}\end{array}$ & $\begin{array}{c}\text { Mreparation and approval of } \\
\text { territorial planning documents } \\
\text { of a settlement }\end{array}$ \\
\hline $\begin{array}{c}\text { technical regulation in the } \\
\text { field of urban development }\end{array}$ & $\begin{array}{c}\text { approval of regional standards } \\
\text { for urban planning }\end{array}$ & $\begin{array}{c}\text { approval of local standards for } \\
\text { urban planning }\end{array}$ \\
\hline $\begin{array}{c}\text { establishing a procedure for } \\
\text { conducting GISOGD }\end{array}$ & $\begin{array}{c}\text { coordination of spatial } \\
\text { planning schemes }\end{array}$ & $\begin{array}{c}\text { approval of land use and } \\
\text { development rules }\end{array}$ \\
\hline $\begin{array}{c}\text { establishing the procedure for } \\
\text { determining the estimated cost } \\
\text { of construction, the formation } \\
\text { and maintenance of a federal } \\
\text { register of estimated standards }\end{array}$ & $\begin{array}{c}\text { monitoring the development } \\
\text { and approval of programs for } \\
\text { the integrated development of } \\
\text { communal, transport, social } \\
\text { infrastructure systems of } \\
\text { settlements, urban districts }\end{array}$ & $\begin{array}{c}\text { issuance of permits for the } \\
\text { construction and reconstruction } \\
\text { of capital construction } \\
\text { facilities, for commissioning of } \\
\text { facilities }\end{array}$ \\
\hline \multicolumn{2}{|c}{} \\
\hline
\end{tabular}

\section{Study areas and analyses}

For the development and normal functioning of settlements, well-developed urban planning documents are required. These include:

1. Documents of territorial planning.

2. Documents of urban zoning.

3. Territory planning documentation.

Territorial planning requires the development of the territory in order to obtain the necessary conditions for use in state or municipal conditions. Exist the two types documents of territorial planning:

1. Territorial planning scheme.

2. General plan.

A territorial planning scheme at each level is necessary to determine the main direction of the implementation of state and municipal policies in the field of urban development, solve land and property issues, develop engineering, transport and social infrastructure and solve other urban development problems, allocate capital objects of federal, regional and municipal property.

One of the types of territorial planning documents that plays a major role in the development of the territory is the general plan of the city district or settlement. The master plan is the main urban planning document that defines the conditions for the formation of the living environment, the direction and boundaries of the development of territories of urban and rural settlements, urban districts, establishes the functional zoning of territories, the development of engineering, transport and social infrastructures, urban planning requirements for the conservation of objects historical and cultural heritage and specially protected natural territories, ecological and sanitary welfare. Master plans for settlements or urban districts are developed for a rather long term and are approved by representative bodies of local government.

General plan is developed in graphical and textual form. The graphic part is a map of the settlement, urban district within the boundaries of municipalities. The map shows the boundaries of the settlement and the municipality, functional zones, objects of federal, regional and local destination. 


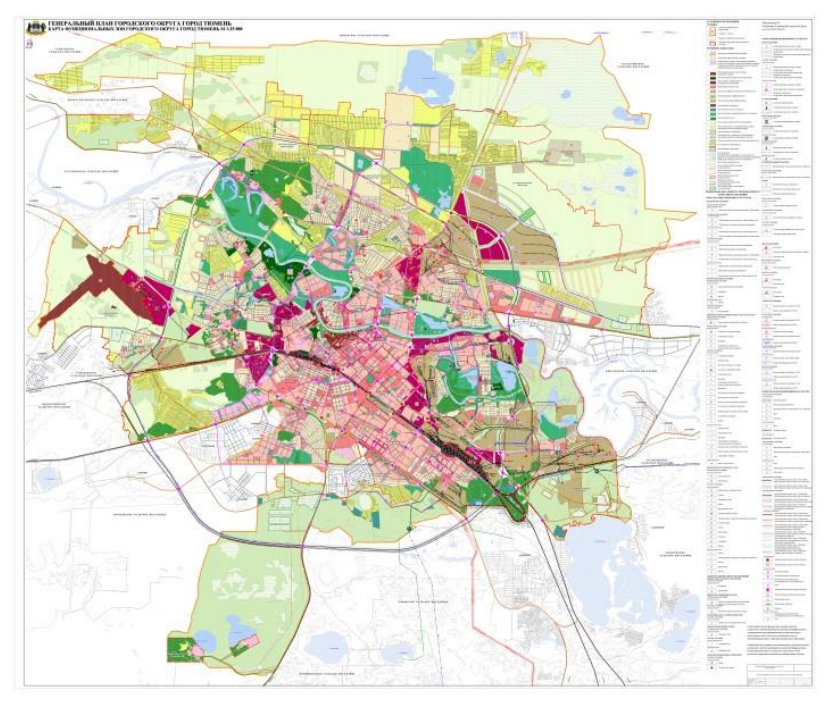

Fig.1 graphic part of the general plan (general plan of the city of Tyumen)

The text part contains a provision on territorial planning, which spells out general provisions, goals, the main tasks of territorial planning, the design part and the program of measures for the implementation of the general plan.

Another type of urban planning documentation is urban zoning documents, which are aimed at dividing the territory within a settlement, urban district, depending on the functional purpose, into zones where urban planning regulations are established. The main purpose of this type of documentation is to establish requirements for the use of the territory. The only representative of the urban zoning documentation is the Land Use and Development Rules.

Land use and development rules - a document of urban zoning, which is approved by regulatory legal acts of local authorities, regulatory legal acts of state authorities of the constituent entities of the Russian Federation - cities of federal significance Moscow, St. Petersburg and Sevastopol and in which territorial zones, urban planning regulations, building parameters are established and structures, the procedure for applying such a document and the procedure for amending it.

Land use and development rules have clearly defined sections:

1. the procedure for their application and amendments to the Land Use and Development Rules;

2. map of urban zoning;

3. urban planning regulations.

The section "The procedure for their application and amendments to the Land Use and Development Rules" considers this type of urban planning documentation from a legal point of view. The powers of local governments in the field of regulation Land Use and Development Rules, the general provisions of the procedure for preparing the Land Use and Development Rules and amendments thereto, the procedure for conducting public hearings are spelled out in detail.

The cartographic material of the Land Use and Development Rules displays the boundaries of territorial zones - zones for which boundaries are defined and urban planning regulations are established. There are 9 territorial zones:

- residential zones (for construction by residential buildings (individual, low, middle and multi-storey buildings), as well as the construction of cultural facilities and other purposes is allowed); 
-public-business zones (for development by administrative buildings, educational, cultural, social and social facilities and other buildings intended for public use);

- production zones (for development by industrial, communal and other facilities intended for production purposes);

- zone of engineering and transport infrastructure (for development by objects of railway, automobile, river, sea, air, pipeline transport, communications, engineering infrastructure);

- recreational zones (for recreation of citizens and tourism (city forests, squares, parks, city gardens, ponds, lakes, reservoirs);

- agricultural use zones (zones occupied by agricultural facilities and intended for agriculture, summer cottage, personal subsidiary plots, gardening, development of agricultural facilities);

- special purpose zones (zones occupied by cemeteries, crematoria, cattle cemeteries, waste disposal facilities and other facilities);

- zones of military facilities (for the deployment of military bases, towns, training grounds, aerodromes, other security and space support facilities, military educational institutions, enterprises, institutions and organizations that perform missions in defense, security and space support);

- zones of specially protected zones (land plots having a special environmental, scientific, historical and cultural, aesthetic, recreational, health and other especially valuable purpose);

- other zones (zones allocated taking into account functional zones and features of the use of land plots and capital construction objects).

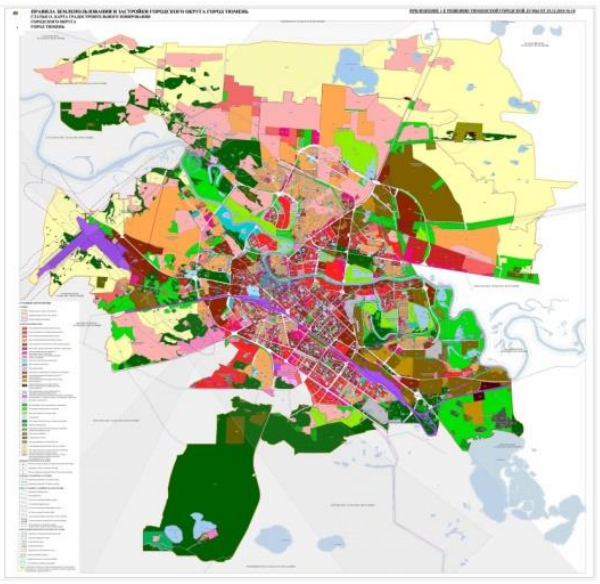

Fig.2 Urban zoning map.

Each territorial zone has its own borders, which can be established along the lines of highways, streets, driveways, red lines, the boundaries of land, settlements (within municipalities) and the natural borders of municipalities. Within the boundaries of territorial zones, urban planning regulations are established.

Town-planning regulations are, in essence, the legal regime of land plots defined within the boundaries of the corresponding territorial zone, as well as everything that is above and below the surface of land plots.

The urban planning regulations for land plots and capital construction sites located within the relevant territorial zone indicate:

1) types of permitted use of land plots and capital construction projects;

2) limit (minimum and (or) maximum) sizes of land plots and limit parameters of permitted construction, reconstruction of capital construction facilities; 
3) restrictions on the use of land and capital construction projects.

Based on the general plan and the Land Use and Development Rules, the following type of urban planning documentation is developed - this is the territory planning documentation, which is being developed in order to ensure the sustainable development of territories, highlight elements of the planning structure (quarters, neighborhoods, other elements) and establish the boundaries of land.

The territory planning documentation includes:

1) a draft layout of the territory;

2) land surveying project.

Territory planning project is a document developed for part of the settlement territory with the aim of highlighting elements of the planning structure and establishing parameters for their planned development.

The planning project consists of two parts: graphic and text.

1) the graphic part - a drawing of the layout of the territory, which displays red lines, the boundaries of existing and planned elements of the planning structure, the boundaries of the zones of the planned placement of capital construction projects, developed on a scale of 1 : 2000 or 1: 1000 ;

2) the text part - the provision on the location of capital construction projects of federal, regional and local destination, the characteristics of the planned development of the territory, as well as the provision on the priority of the planned development of the territory.

Another type of territory planning documentation is a land surveying project, which is a document that displays the main lines of regulation of development within the boundaries of elements of the planning structure. A land surveying project can be developed as part of a territory planning project, or as a separate document. The main task that the land surveying project solves is the determination of the size and boundaries of land plots, the establishment of urban planning requirements for their use.

Unlike the territory planning project, only the graphic part is present in this type of documentation. The text part in the project of land surveying is inexpedient, since all design decisions on the development of an element of the planning structure are justified in the project for planning the territory.

The drawing of the land surveying project shows red lines, indent lines from red lines, borders of planned and existing elements of the planning structure, existing easements, borders of zones with special conditions for the use of territories, borders of created or modified land plots, borders of specially protected natural territories, boundaries of objects' territories cultural heritage.

Further development of the elements of the planning structure should be carried out in accordance with the project planning of the territory and the project of land surveying.

A special type of urban planning documentation, which was previously one of the types of territory planning documentation, is the urban development plan of a land plot, which is necessary to provide urban development entities with the information necessary for architectural and construction design, construction, reconstruction of capital construction projects in land boundaries.

At its core, the urban development plan of the land is a document in which it is duplicated

information from the master plan, land protection zone, planning and land surveying projects and information necessary for building on a specific land plot:

- details of the project planning and land surveying of the territory;

- boundaries of the land;

- cadastral number of the land plot (if any);

- minimum indentation from the boundaries of the land;

- type of permitted use; 
- limit parameters of permitted construction, reconstruction of the capital construction facility;

- calculated indicators of the minimum acceptable level of provision of the territory with objects of communal, transport, and social infrastructures;

- land restrictions;

- the boundaries of zones with special conditions for the use of territories;

- the boundaries of public easements;

-Technical conditions for connecting capital construction facilities to engineering and technical support networks;

- red lines;

- number and (or) name of the element of the planning structure, within the boundaries of which the land plot is located;

- details of the regulatory legal acts of a constituent entity of the Russian Federation, municipal legal acts establishing requirements for the improvement of the territory.

A necessary tool for the management of urban areas is the information system for urban development (ISOGD) is a comprehensive multi-stage project that provides automation and electronic interagency interaction in the planning and management of the development of the territory. ISOGD provides interconnected planning, management and control at the stages from strategic territorial planning to solving tactical issues on the formation of land plots, issuing building permits and putting individual facilities into operation.

Starting January 1, 2019, it becomes mandatory to maintain a systematic set of documented information on the development of territories, their development, land plots, capital construction objects and other information necessary for urban development - the state information system for urban development (hereinafter referred to as GISOGD). During the year when the changes come into force, all executive authorities will have to create and (or) bring the operating GISOGD into line with the requirements of the law. Three years are allotted for the placement of information contained in municipal systems. The composition of the information resources, which includes the GISOGD, differs from the previously established for the municipal GISOGD.

At the moment, the following are displayed in the GISOGD:

- maps of the planned location of federal facilities and regulations on territorial planning in relation to the territory of constituent entities of the Russian Federation, provided for by the territorial planning scheme of the Russian Federation;

- maps of the planned location of regional objects and provisions on territorial planning in relation to the territory of constituent entities of the Russian Federation, provided for by the territorial planning scheme of two or more constituent entities of the Russian Federation;

- maps of functional zones and the planned location of federal, regional, local significance objects and provisions on territorial planning, provided for by the territorial planning scheme of the municipal district and the General Plan of urban districts and settlements;

- regional standards for urban planning;

- local standards for urban planning;

- Rules of land use and development;

- rules for landscaping;

- The main part of the territory planning project;

- The main part of the project for land surveying;

- materials and results of engineering surveys;

- information on the creation of an artificial land plot;

- information on the boundaries of zones with special conditions for the use of territories; 
- provisions on specially protected natural territories, forestry regulations of the forestry, forest park located on the lands of the forest fund;

- plan of ground and underground communications;

- decisions on the reservation of land or decisions on the seizure of land for state or municipal needs;

- cases of built-up and subject to development land plots;

- Programs for the integrated development of social, communal and transport infrastructure systems.

\section{Conclusion}

After analyzing all types of urban planning documentation, we can conclude that the master plan, the rules of land use and development, the project of planning and land surveying of the territory is a necessary tool for making managerial decisions.

For more effective management, an integrated approach to its development is required, as well as providing state authorities, local governments, individuals and legal entities with reliable information necessary for urban development in the form of a systematic set of documented information - ISOGD.

Today, in urban planning, ways to efficiently manage the development of territories are provided, which ensure the creation of a comfortable environment for the life of the population.

\section{References}

1. A.V. Kryahtunov, Development of urban management tools at the present stage (2019)

2. A. M. Hassan, H. Lee, Lan. Us. Pol., 48, 199-212 (2015) 